\section{Specialist en generalist}

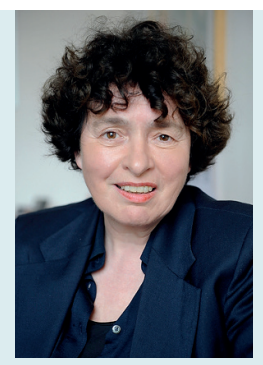

We weten het allemaal: palliatieve zorg gaat per definitie over interdisciplinaire zorg. We hebben oog voor lichamelijke en psychosociale problemen, voor zingeving en spiritualiteit. Als zorgverlener ben je specialist ten aanzien van je eigen expertise, en hoor je generalist te zijn op andere gebieden. En weet je wanneer je moet doorverwijzen.

Recente ontwikkelingen laten zien hoe we werken aan verdieping en verbreding op dit gebied. $\mathrm{Na}$ de introductie van het kwaliteitskader op het Nationale Congres Palliatieve zorg in 2016, was het tijd voor een volgende stap: op 26 april werd het congres 'Kwaliteitskader palliatieve zorg Nederland; van papier naar praktijk' gehouden, waarin bovenstaande aspecten verder zijn besproken en verdiept. Ook refereer ik graag aan het boek Slotcouplet van Sander de Hosson. Niet om de wijze waarop het in de markt wordt gezet met termen als 'compassie, liefde en écht contact' (emo-literatuur?), maar omdat hij in dit boek zichtbaar maakt hoe hij zijn eigen vorm heeft gevonden tussen specialist en generalist zijn. Dat doen we allemaal op onze eigen manier en zo'n voorbeeld kan ondersteunend zijn bij je eigen zoektocht. Tot slot noem ik graag nog het promotieonderzoek van Everlien de Graaf: Verkenning van de inhoud van de professionele hospicezorg in Nederland vanwege de nadruk op 'Het Utrecht Symptoom Dagboek (USD)' als patiëntuitkomst. Dit draagt zeker bij aan het inzichtelijk maken van multidimensioneel lijden van patiënten. Als patiënten het op kunnen brengen de USD in te vullen, kan dit bijdragen aan het op een methodische wijze centraal zetten van de behoeften van patiënten. Wat het zeker doet, is ons in de interdisciplinaire samenwerking in contact brengen met andere disciplines. En zorgen voor verbreding in ons denken over palliatieve zorg, en over onszelf als specialist en generalist. Ik hoop dat de artikelen in deze Pallium ook bijdragen aan deze zoektocht.

\section{Marie-José Gijsberts}

Specialist ouderengeneeskunde en redactielid Pallium

\section{7 september 2018 - Bewegen,} beleven rond het sterven

Bewuste kwaliteit en onbewuste kracht worden gestimuleerd in deze multidisciplinaire masterclass. Meer informatie: www.leerhuizenpalliatievezorg.nl.

\section{8 september 2018 - Palliatieve Zorg Congres}

Versterk uw rol in verzachting van lijden en een waardige afronding van het leven van uw patiënten. Met aandacht voor zorg bij cognitieve beperkingen (Marijke Tonino), ethische kwesties (Carlo Leget) en euthanasie (Hans van Dam). Meer informatie: www.nursing.nl.

\section{5 oktober 2018 - Nationale Congres voor Hospicezorg}

Mooie thema's, goede sprekers, interessante workshops. Meer informatie: www.congressenmetzorg.nl.

\section{1 oktober 2018 - Euthanasie als} behandeloptie bij psychisch lijden? Symposium van de NVVE en de Levenseindekliniek over in hoeverre euthanasie een serieuze behandeloptie kan zijn bij psychisch lijden. Meer informatie: euthanasiebijpsychischlijden.nl.

\section{3 oktober 2018 - Internationale Dag van de Palliatieve Zorg}

Op deze dag vinden overal activiteiten plaats, van kennismaking tot verdieping. Houd vanaf september social media en websites in de gaten van de Netwerken Palliatieve Zorg, hospices, ziekenhuizen, mantelzorgorganisaties en vrijwilligersorganisaties voor activiteiten. In tweets kijkt u op \#DPZ2018.

\section{6 november 2018 - Workshop}

\section{Instrumenten in de palliatieve zorg}

Aandacht voor verdieping van het Utrechts Symptoom Dagboek, de Signaleringsbox, het Palliatief Redeneren en het Zorgpad Stervensfase. Meer informatie: www.leerhuizenpalliatievezorg.nl.

\section{7 - 9 november 2018 - 7e Nationaal congres palliatieve zorg \\ 'Palliatieve zorg voor iedereen; van kwaliteitska- der naar unieke patiënt' is dit keer het thema. \\ Meer informatie: www.palliactief.nl.}

\title{
Everlien De Graaf
}

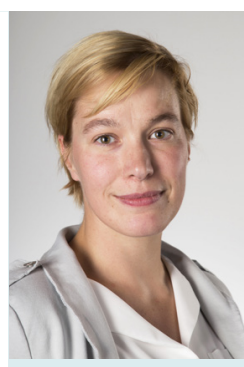

Everlien de Graaf is senior onderzoeker bij UMC Utrecht en promoveerde onlangs op onderzoek naar de hospicezorg in Nederland, met speciale aandacht voor symptoomlijden en welbevinden.

Welke conclusies komen er uit het onderzoek? "Organisatorisch is de zorg in hospices goed neergezet, maar op operationeel niveau is er veel verschil. Bijvoorbeeld als het gaat om multidisciplinaire samenwerking. Zorgprofessionals die betrokken zijn bij de hospicezorg kunnen met elkaar overleg voeren, maar de zorg vanuit hun eigen visie en functie blijven benaderen. Dan is er geen sprake van interdisciplinariteit. Om werkelijk in kaart te kunnen brengen wat patiënten op lichamelijk, psychisch, sociaal en spiritueel vlak nodig hebben, is dat wel van belang."

Wat hebben jullie ontdekt over symptoomlijden en welbevinden?

"Veel problemen hebben een multidimensioneel karakter. Dat heeft te maken met symptomen in de verschillende dimensies die elkaar beïnvloeden, maar ook met de waarde die een patiënt aan een symptoom toekent. In het Utrecht Symptoom Dagboek worden nu alleen nog fysieke en psychische symptomen opgenomen. Wij zijn bezig om ook de sociale en spirituele aspecten hierin op te nemen."

\section{Uit het promotieonderzoek is het HOPEVOL} Project ontstaan. Wat houdt dat in?

"Het promotieonderzoek is alleen gebaseerd op gegevens van patiënten in de afgelopen tien jaar van Academisch Hospice Demeter. Wat betreft de organisatorische vragen hebben we de 43 hospices meegenomen die zijn aangesloten bij de Associatie Hospicezorg Nederland. We weten niet of de uitkomsten voor alle hospices gelden, daarom gaan we in het vervolgproject na wat patiënten ervaren en of interventies het gewenste effect hebben. Het doel is om tot een blauwdruk van een toekomstbestendige hospicezorg te komen." 